\title{
Economic Socialization of Senior Schoolchildren in the Conditions of the Extreme North
}

\author{
Ekaterina V. Malakhova ${ }^{a}$, Vladimir I. Kirko ${ }^{a, b}$ \\ and Marina G. Yanova ${ }^{\text {a* }}$ \\ ${ }^{a}$ Krasnoyarsk State Pedagogical University \\ named after V.P. Astafiev \\ 89 Ada Lebedeva Str., Krasnoyarsk, 660049, Russia \\ ${ }^{b}$ Siberian Federal University, \\ 79 Svobodny, Krasnoyarsk, 660041, Russia
}

Received 21.03.2018, received in revised form 05.08.2018, accepted 15.08.2018

This paper shows the results of comparative studies on identifying the level of economic culture among the senior schoolchildren belonging to indigenous peoples of the Extreme North.

Within this work, the students' environment is being studied; the levels of schoolchildren's socialization as well as their differences are being marked.

The method used in the work can be applied in educational institutions of secondary and general education to increase the level of economic culture among the students in order to encourage them on becoming useful for the society they represent and live in.

The differentiation of the senior schoolchildren according to the level of their social adaptation which shows universal competences demanded for living in the modern socio-economic environment is being revealed.

Keywords: economic culture, senior schoolchildren, indigenous peoples, socialization, conditions of the Extreme North.

This research has been provided under the Regional Competition at the Department Humanities and Social Studies of the Russian Foundation of Basic Research "The Power of Russia will be increased by Siberia and the Arctic Ocean”, 2017 - Krasnoyarskiy Krai sponsored by the Krai State Autonomous Institution "Fund for Supporting Scientific and R\&D Activity in Krasnoyarskiy Krai"; the project "Development and Reproduction of Human Capital Assets as the Basis for Improving the Quality of Life of Indigenous People of the North and Arctic in Krasnoyarskiy Krai in the Terms of Traditional Environmental Management" No. 17-16-24004.

Research area: pedagogical sciences.

Citation: Malakhova, E.V., Kirko, V.I., Yanova, M.G. (2018). Economic socialization of senior schoolchildren in the conditions of the Extreme North. J. Sib. Fed. Univ. Humanit. soc. sci., 11(8), 1301-1314. DOI: 10.17516/1997-1370-0307.

(C) Siberian Federal University. All rights reserved

* Corresponding author E-mail address: malkaterok@mail.ru; director.nifti@mail.ru; ymg_boss@mail.ru 


\section{Introduction}

Throughout the centuries the Russian state has been supporting original socioeconomic and ethnocultural life of indigenous peoples of the North.

Rough natural and climatic conditions, vulnerability of traditional lifestyle and small number of each people of the North has determined the necessity to form an exclusive state policy concerning their sound development, which suggests a framework for preserving the authentic culture, traditional way of life and unique environment for these people.

To teach the children of reindeer herders, fishermen and hunters, especially in their native language, there are general education day-schools and boarding schools in the settlements and places of economic activities of indigenous Nordic peoples. The areas of nomadic life have also been encouraged to establish nomadic schools, where children acquire elementary education regarding their traditional way of life (Kontseptsiya ustoichivogo razvitiya..., 2009; Vasil'ev et al., 2014).

Meanwhile, despite attempted measures, in recent decades the situation around indigenous peoples of the North has been worsened by inadaptability of their lifestyle to the modern economic conditions. Low competitive performance is caused by low outputs, high transport costs, absence of sophisticated enterprises and technologies designed for complex processing of raw materials and biological resources. Such recession of traditional economic activities has sharpened social problems (Plan meropriiatiy po realizatsii..., 2016; Nevzorov et al., 2017).

Seeking a solution for encouraging economic socialization of youngsters in the Extreme North for the socio-economic and ethnocultural development of indigenous peoples of the North, the authors have observed some findings of the overseas researches.

Traditional business which supports creation and extension of cultural values of ethnic groups has been addressed by S. Danes, J. Lee, K. Stafford, R. Heck. In their researches, the authors find out complex and interdependent links between the family, traditional economic activities and community, in which these ethnic groups work. Traditional business allows preserving cultural context for the ethnic groups, expanding and sharpening family business based on behavior, multilateral theory of family firms, through explaining the fact that it regards combined ethnic firms in their cultural context (Danes et al., 2008).

The role of economic socialization in youngsters' economic behavior has been investigated by P. Webley and E. Nyhus through four different vectors of economic socialization (pocket money allowance, house working, working for others and 
supporting parents). Those youngsters who have been encouraged on savings and taught budget are more responsible as well as more future-oriented and able to control their spending. Thus, the entire economy of young people in their future depends on their psychology and parenting during the teenage years (Webley, Nyhus, 2013).

Under the idea of consumer economic socialization B. Ivan and L. Dickson consider the following questions: economic socialization; skills for children and teenagers development concerning awareness and participation in economic consumer-related processes; and key factors of economic socialization, including culture, mass media, schools, peers and families (Ivan, Dickson, 2008). C. Gudmunson and S. Danes (2011) have also covered family's financial literacy through the perspective of socialization.

The works by R. Mistry, E. Vandewater, A. Huston and V. McLoyd contain the fact that parents' neutrality towards children' economic socialization in their families can critically affect the way of overcoming economic challenges for the social adaptation. The cohort studies have demonstrated that the economic challenges govern children's behavior (Mistry et al., 2002).

Socialization of school children as consumers is a process in which an individual permanently remains congruent to the environment, learning or changing attitudes, values or existing norms. Consumer socialization is possible only through interaction between individual factors (including age, sex, socio-economic status and life period), factors of socialization (including family, school, mass media and cultural differences) and learning techniques (cognitive development and theory of social learning). Thus, such characteristics as knowledge, attitudes and skills, which impact different performances of consumers and support harmonization, fall within the scientific scope (Hayta, 2008).

On the basis of the above, economic socialization of young people directly depends on parenting in childrearing, subjective environment (society, school, family), where the teenager lives. Therefore, those knowledge and skills, acquired in the process of school education, can help young people in developing traditional business that, in turn, would allow preserving cultural heritage for the indigenous ethnic groups.

Regarding the researches, we consider economic socialization with reference to economic culture development. Economic culture means framing a vision for the economic laws of social development and, thereupon, building such personal features which are essential for people in business performance and economic activity. This culture is linked to training students for their life and work. It also represents one of the requirements for a schoolchild to become civic-minded. Among the tasks on building 
economic culture among students we consider: shaping economic thinking; economical habits, tough-mindedness and thrift and acquiring basic skills on economic analysis and providence (Malakhova et al., 2017).

One of the main features of economic culture is that it accumulates mainly those values of the whole culture which are applicable to the sphere of economic behavior and influence it - either positively or negatively. In this context, economic culture plays a significant role in oncoming self-determination of senior schoolchildren, in their personal and professional identification.

The parts of personal socialization are represented through the developed economic culture, consciousness, identity, self-determination, behavior as well as attitude to property and engagement in economic roles maintaining.

An essential unit of economic culture is a body of economic knowledge shared by the society and actualized through the values, norms, standards and motives of behavior which guide the person, group or community (professional, territorial, etc.).

Thus, economic culture is considered as involving individuals into local economic community, characterized by its features. Moreover, it is worth mentioning that socialization forms mainly economic thinking, which, in turn, contributes to the enhancement of public activity, leadership and sense of ownership.

Economic thinking of a student means a part of their own worldview that, in turn, adds value of the real economic knowledge and visions essential for the youngsters.

The current economic challenges give the lead to the sense of information space, flexibility, mobility, ability to work in team and interest on building personal values and the whole society (Malakhova et al., 2017).

For successful and easy self-fulfilment within certain socio-cultural and economic space, the person needs a high level of economic competences and culture.

Such competences are regarded as a set of knowledge, skills and attitudes in the relevant field. In other words, the competences reveal ability to actualize acquired theory ("what" - knowledge transformed into "how" - knowledge), obtained character, "proficiency" in the competency-based paradigm.

Economic competences are determined by a set of theoretical and practical skills necessary to be integrated into the economic system. The competences have knowledge basis and support practical transformation into skills. They assess possibilities of student's self-realization in the future both in profession and in personal life. In such a manner, economic competences are regarded as a means of forming life's vector, career, success and etc (Malakhova, et al., 2017). 
The difference between economic culture and economic competences lies in the fact that the level of economic culture is governed by a depth of human socialization, while economic competences are formed under specifically managed activity, including education.

With the help of socialization we get the conditions (environment) to group children on mutual characteristics in order to analyze the level of their economic culture.

The survey on the economic culture of senior schoolchildren has been conducted in the educational institutions of the Republic of Sakha (Yakutiya) and the Taimyr Dolgano-Nenetskiy Municipal District in Krasnoyarskiy Krai:

- Municipal Budgetary Educational Institution "Olenyokskaya Secondary General School named after Kh.M. Nikolaev", Olenyokskiy Evenk National Nasleg, the Republic of Sakha (Yakutiya);

- Municipal Educational Institution "Secondary Boarding School named after G.M. Vasilevich", Iengra, Neryungrinskiy District, the Republic of Sakha (Yakutiya);

- State Budgetary Educational Institution "Experimental Boarding School "Arktika" (Humanities and Culture Concentration)", Neryungi, the Republic of Sakha (Yakutiya) - for the children of indigenous peoples of the North (hereafter - CIPN) from Arctic areas of the Republic of Sakha (Yakutiya);

- Taimyr Municipal Public Educational Institution "Khatangskaya Secondary School \#1", Khatanga, Taimyr Dolgano-Nenetskiy Municipal District;

- Taimyr Municipal Public Educational Institution "Khatangaskaya Secondary Boarding School", Khatanga, Taimyr Dolgano-Nenetskiy Municipal District - for the

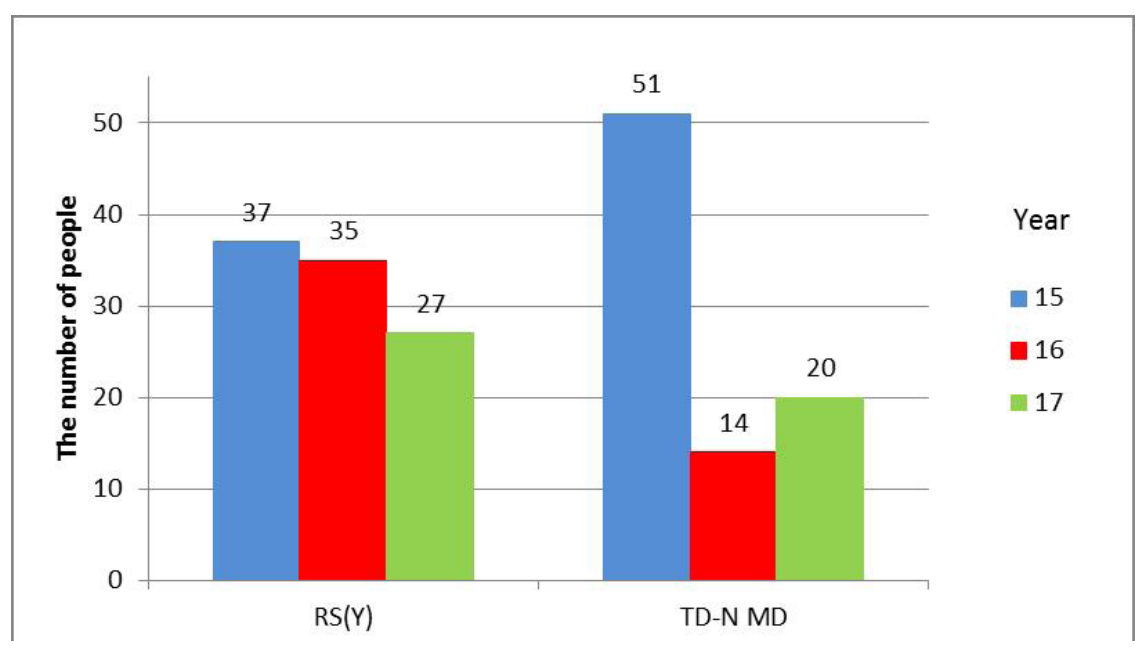

Fig. 1. Distribution of the respondents on age and area basis 
CIPN from the settlements of the North Circle, Krasnoyarskiy Krai (Popigay, Kresty, Novorybnaya, Karaul, Kheta, etc.).

The number of the respondents - representatives of the indigenous peoples - is 234 and 184 children aged 15-17 out of all the schoolchildren of 9-11 grades (Fig. 1).

\section{Methods}

This research has been conducted by the procedures mentioned in "Career Choices Made by Middle and High Schoolchildren with the Main Focus on Representatives of Indigenous Peoples of the North in the Republic of Sakha (Yakutiya)" basing on specifically designed inquiry form (Kirko et al., 2017).

To analyze the level of economic culture among the senior schoolchildren in the Extreme North, we have used the method of assembling and classifying statistical observations, calculating the average margin of error through the Student's coefficient.

Basing on the survey's data we have built the spidergrams, the areas of which demonstrate the results referring to the corresponding blocks. It allows achieving better presentation of the considered subject (Fig. 2-5).

To map the diagrams, we have measured the average data on the indicators in each module and compared them with the average indicator per a module.

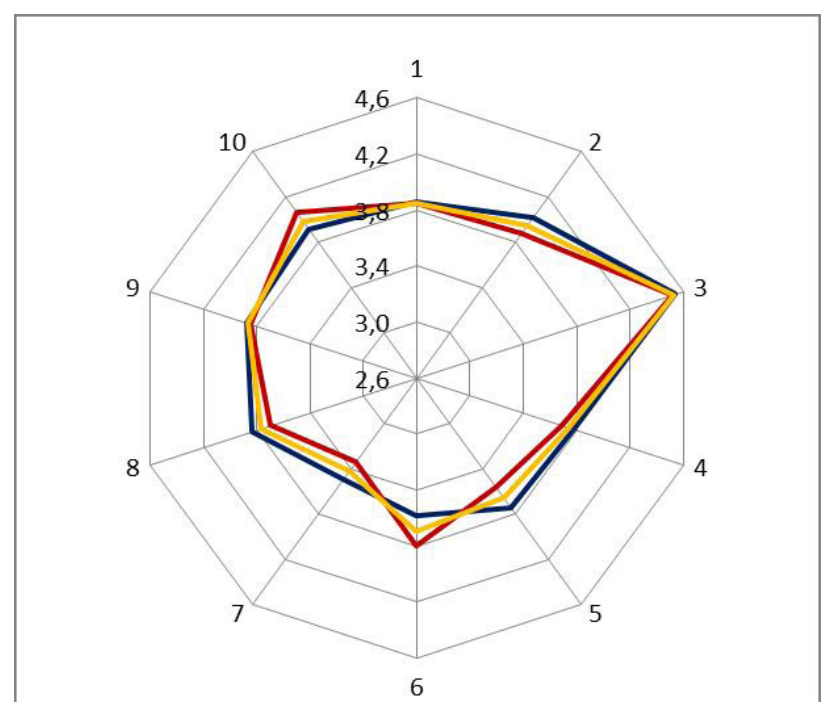

Fig. 2. Indicators for communication module: 1 - soft skills; 2 - relationships with teachers; 3 relationships with parents; 4 - confidence in communication with the opposite sex; 5 - confidence in emotional communication; 6 - ability to cooperate in a team; 7 - confidence within business communication; 8 - tolerance; 9 - ability to take a situation; 10 - sociability 


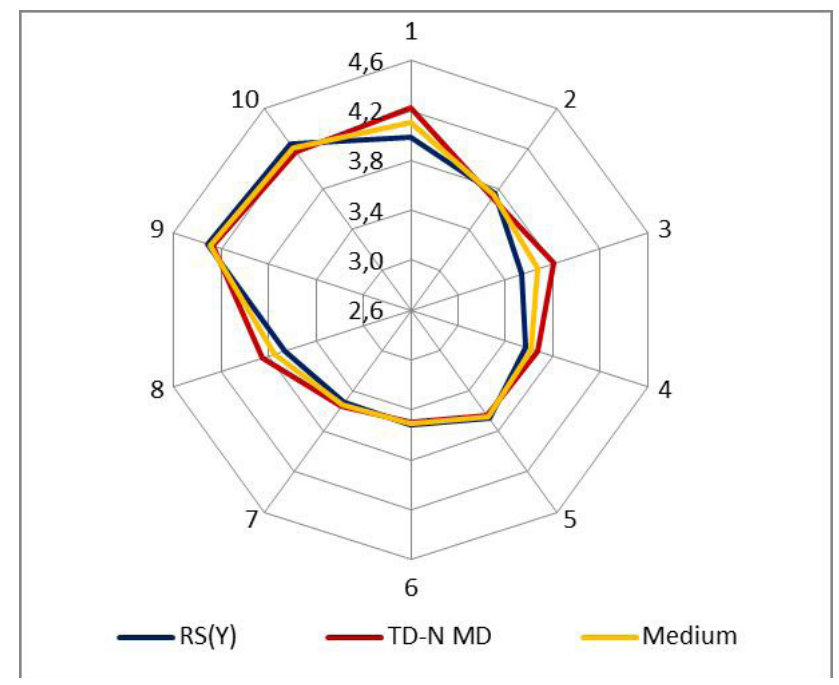

Fig. 3. Indicators for psychological module: 1 - responsible attitude to oneself; 2 -interpersonal skills; 3 - self-esteem adequacy; 4 - creativity; 5 - strong interest; 6 - reflexivity; 7 - critical thinking; 8 self-belief; 9 - self-dependence; 10 - self-respect

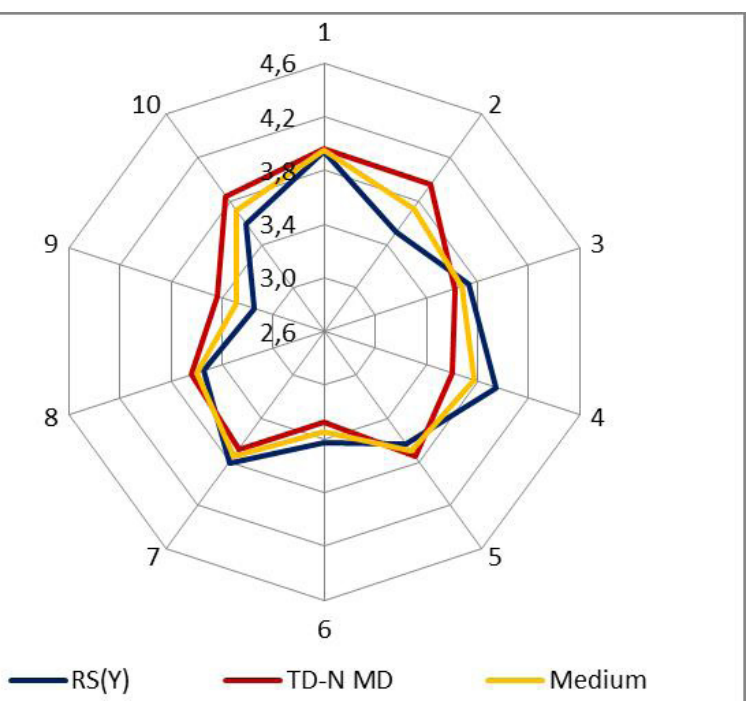

Fig. 4. Indicators for instrumental module: 1 - housework; 2 - wise attitude to money spending; 3 budget awareness; 4 - knowing how to earn a living; 5 - formed working knowledge; 6 - knowledge about resources; 7 - PC skills; 8 - fluency in reading; 9 - ability to overcome crisis; 10 - intention to keep fit

In this module, the data differs slightly. It proves the fact that the children identify themselves as quite communicative. Still, each district has its own troubled zones: concerning the Republic of Sakha (Yakutiya) such zones are ability to cooperate in a team and sociability, while in Taimyr Dolgano-Nenetskiy Municipal District - 


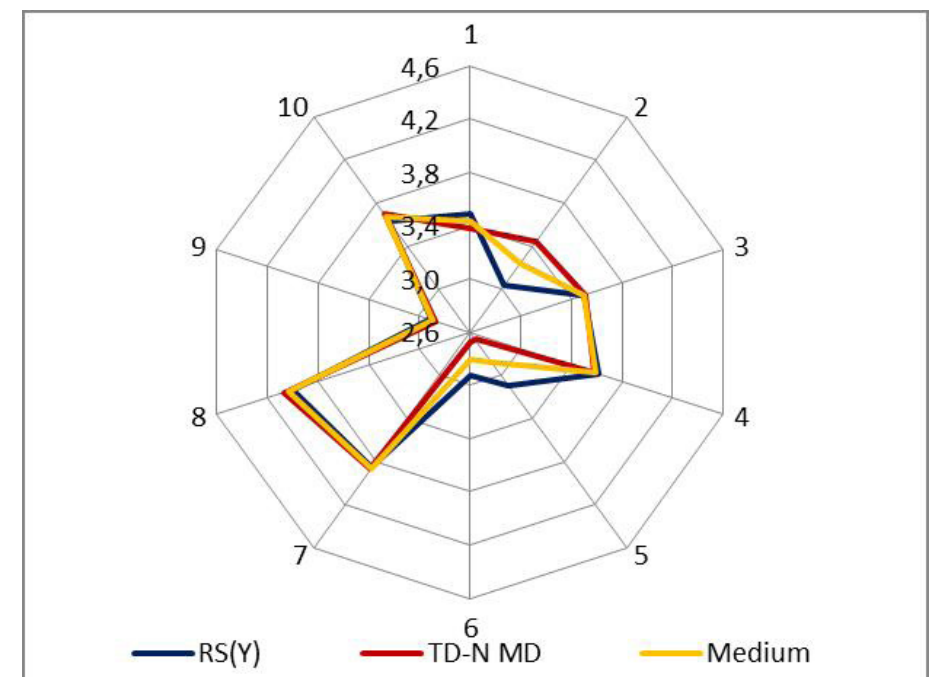

Fig. 5. Indicators for social module: 1 - practical mind; 2 - ability to say "no"; 3 - readiness to reach a compromise; 4 - tolerance; 5 - knowledge of market realia; 6 - awareness of methods and ways on tackling economic problems; 7 - life plans; 8 - awareness of rights and responsibilities; 9 - extracurriculum knowledge; 10 - competency

relationship with teachers, confidence in emotional and business communication as well as tolerance.

The module shows that the data on three indicators is directly opposite. While in Taimyr Dolgano-Nenetskiy Municipal District responsible attitude to oneself, self-esteem adequacy and self-belief tend to higher results, in the Republic of Sakha (Yakutiya) these indicators are lower than the average ones.

The instrumental module highlights that gap between the schoolchildren from Yakutiya and Taimyr. For most of the measures in the Republic of Sakha (Yakutiya) the data does not reach the average rate.

Most of the respondents are the students of boarding schools for indigenous peoples of the North, whose parents are nomadic in taiga or tundra. Since the module includes the questions on identifying wide knowledge and skills (wise attitude to money spending, budget awareness and others), so the children have provided us with such low figures due to absence of these skills - they (children) are hardly involved in such activities. Although, if compared to Taimyr Dolgano-Nenetskiy Municipal District, the Yakut children have deeper understanding of budget, they know about resources and ways of earning and are better at PC skills.

This module reveals a serious gap between the data relevant for the Republic of Sakha (Yakutiya) and Taimyr Dolgano-Nenetskiy Municipal District on three parameters. 
Table 1. Contents of spidergrams

\begin{tabular}{|l|c|c|c|c|c|}
\hline & $\begin{array}{c}\text { Communication } \\
\text { module }\end{array}$ & $\begin{array}{c}\text { Psychological } \\
\text { module }\end{array}$ & $\begin{array}{c}\text { Instrumental } \\
\text { module }\end{array}$ & $\begin{array}{c}\text { Social } \\
\text { module }\end{array}$ & Total area \\
\hline Republic of Sakha (Yakutiya) & 0,99 & 1,01 & 1,02 & 0,99 & 4,01 \\
\hline $\begin{array}{l}\text { Taimyr Dolgano-Nenetskiy } \\
\text { Municipal District }\end{array}$ & 1,01 & 0,99 & 0,98 & 1,01 & 3,99 \\
\hline Average measure per module & 1,00 & 1,00 & 1,00 & 1,00 & 4,00 \\
\hline
\end{tabular}

It contains the questions which address universal competences required for living in the modern social environment. While the schoolchildren in Taimyr DolganoNenetskiy Municipal District can make decision on their own and say "no", still, they have no knowledge of market realia as well as no awareness of methods and ways on tackling economic problems.

Comparative analysis of the relative areas of spidergrams have provided with the results (contents) which permit benchmarking on the modules (Table 1).

Fig. 6 represents a histogram on the mastered levels of schoolchildren's socialization regarding the territory.

Basing on the data received, we can conclude that the levels of socialization in senior schoolchildren are being formed on an equal footing.

As it appears from (6) the schoolchildren in the Republic of Sakha (Yakutiya) build their level of socialization considering the psychological and instrumental modules, while in Taimyr Dolgano-Nenetskiy Municipal District - on the communication and social modules.

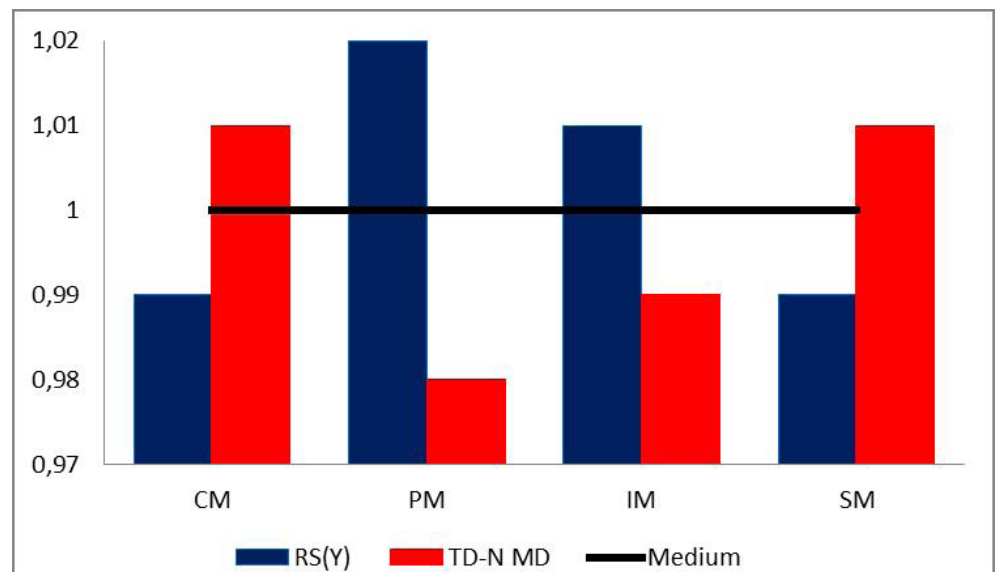

Fig. 6. Mastered levels of schoolchildren's socialization regarding the territory 


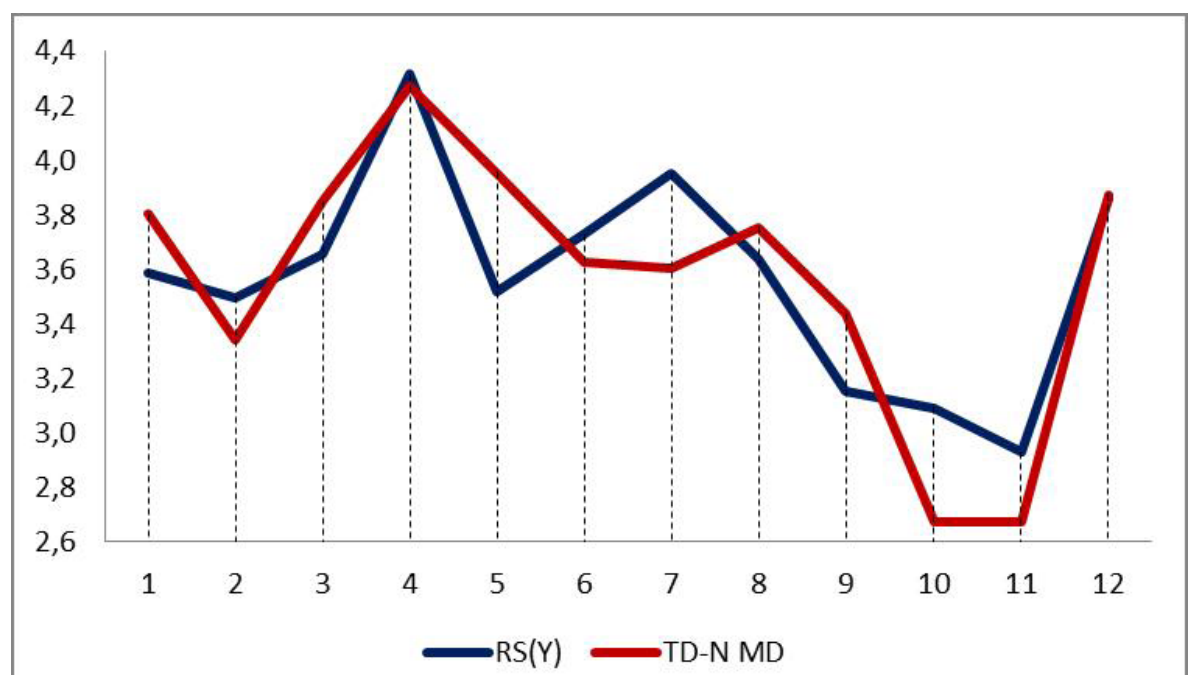

Fig. 7. Levels of economic culture development in schoolchildren regarding the territory

The level of economic culture development has been also measured regarding 12 indicators: ability to cooperate in a team, confidence in business communication, self-confidence, self-dependence, wise attitude to money spending, budget awareness, awareness of the ways to earn a living, practical skills, ability to overcome crisis, awareness of market realia, awareness of methods and ways to tackle economic problems and availability of life plans. The results of such measurement are shown in Fig. 7 and Table 2.

Table 2. Data on the levels of economic culture development among schoolchildren

\begin{tabular}{|c|c|c|c|}
\hline & $\begin{array}{c}\text { Republic of Sakha } \\
\text { (Yakutiya) }\end{array}$ & $\begin{array}{c}\text { Taimyr Dolgano-Nenetskiy } \\
\text { Municipal District }\end{array}$ & $\begin{array}{c}\text { Deviation } \\
\left|\mathrm{x}_{1}-\mathrm{x}_{2}\right|\end{array}$ \\
\hline 1 & 3.6 & 3.8 & 0.2 \\
\hline 2 & 3.5 & 3.3 & 0.2 \\
\hline 3 & 3.7 & 3.8 & 0.2 \\
\hline 4 & 4.3 & 4.3 & 0.0 \\
\hline 5 & 3.5 & 4.0 & 0.4 \\
\hline 6 & 3.7 & 3.6 & 0.1 \\
\hline 7 & 3.9 & 3.6 & 0.3 \\
\hline 8 & 3.6 & 3.8 & 0.1 \\
\hline 9 & 3.2 & 3.4 & 0.3 \\
\hline 10 & 3.1 & 2.7 & 0.4 \\
\hline 11 & 2.9 & 2.7 & 0.3 \\
\hline 12 & 3.9 & 3.9 & 0.0 \\
\hline
\end{tabular}


Fig. 7 and Table 2 include indicators with significant disparities in the economic culture among the schoolchildren in these regions. Regarding the ones in the Republic of Sakha (Yakutiya), the most important issues for the economic culture formation are awareness of the ways to earn a living (instrumental living), awareness of market realia and methods on tackling economic problems (social module). Senior schoolchildren in Taimyr Dolgano-Nenetskiy Municipal District are mainly focused on wise attitude to money spending and ability to overcome crisis (instrumental module).

\section{Conclusion}

Considering the findings on the mastered level of socialization and economic culture development in the senior schoolchildren of the Extreme North, we are drawing the following line. Having compared the indicators in communication and psychological modules, we now may note that there is almost no differentiation, while between the instrumental and social modules it can be traced through a number of measures. As for the instrumental module, the gap can be seen in such parameters as wise attitude to money spending and awareness of money making.

In the social module this differentiation emerges in ability to make decisions on one's own and to say "no", in awareness of market realia and ways to tackle economic problems.

Having identified these differences in the levels of economic culture development, we can figure out conditions for the further high level of schoolchildren's socialization. Mastering a high level of economic culture makes schoolchildren open for being integrated into the socio-cultural and economic space.

We have assessed the environment, identified the levels of schoolchildren's socialization and mechanisms for the further growth in the level of economic culture and, thus, development of students' economic socialization aimed at motivating schoolchildren to become useful for the society they represent and live in order to preserve and strengthen that distinctive character of indigenous peoples of the North.

\section{References}

Danes, S.M., Lee J., Stafford, K., Heck, R.K.Z. (2008). The Effects of Ethnicity, Families and Culture on Entrepreneurial Experience: An Extension of Sustainable Family Business Theory, In Journal of Developmental Entrepreneurship, 13 (03), 229-268.

Gudmunson, C.G., Danes, S.M. (2011). Family Financial Socialization: Theory and Critical Review, In Journal of Family and Economic Issues, 32 (4), 644-667. 
Hayta, A.B. (2008). Socialization of the Child as a Consumer, In Family and Consumer Sciences Research Journal, 37 (2), 167-184.

Ivan, B., Dickson, L. (2008). Consumer Economic Socialization, In Handbook of Consumer Finance Research. New York, Springer, 83-102.

Kirko, V.I., Evseenko, E.A., Malakhova, E.V., Koptseva, N.P. (2017). Career Choices Made by Middle and High Schoolchildren with the Main Focus on Representatives of Indigenous Peoples of the North in the Republic of Sakha (Yakutiya), In Novosibirsk State Pedagogical University Bulletin, 7 (6), 7-25. DOI: 10.15293/2226-3365.1706.01.

Kirko, V.I., Koptseva, N.P., Malakhova, E.V., Razumovskaya, V.A., Yanova, M.G. (2018). Characteristics of Economic Socialization of High School Students in the Northern Territories of Krasnoyarsk Krai and the Sakha (Yakutiya) Republic, In Novosibirsk State Pedagogical University Bulletin, 8 (2), 209-221. DOI: 10.15293/22263365.1802.12.

Kontseptsiya ustoichivogo razvitiya korennykh malochislennykh narodov Severa, Sibiri i Dal'nego Vostoka Rossiyskoi Federatsii [The Conception of Sustainable Development for the Indigenous People of the North, Siberia and Far East in the Russian Federation] (2009). Available at: http://gov.garant.ru/SESSION/PILOT/main.htm

Malakhova, E.V., Kirko, V.I., Yanova, M.G. (2017). Otsenka urovnia ekonomicheskoi kul'tury obuchayushchikhsia severnykh territoriy Krasnoyarskogo kraia i Respubliki Sakha (Yakutiya) [Assessment of the Level of Economic Culture in School Students of the Northern Territories of Krasnoyarskiy Krai and the Republic of Sakha (Yakutiya)], In Sovremennoye obrazovanie [Modern Education]. 4, 26-38. DOI: 10.25136/24098736.2017.4.24510.

Malakhova, E.V., Stepanov, E.A., Yanova, M.G. (2017). Formirovanie ekonomicheskikh kompetentsiy kak odin iz faktorov sotsializatsii starshikh shkol'nikov v usloviiakh Krainego Severa [Formation of Economic Competences as One of the Factors of Senior Schoolchildren's Socialization in the Conditions of the Extreme North], In Mir cheloveka: materialy ezhegodnykh konferentsiy [Human World: Proceedings of Annual Conferences], 1 (45), available at: https://www.sibsau. ru/images/nauka/2017_vypusk\%20145_Mir\%20cheloveka.pdf

Mistry, R.S., Vandewater, E.A., Huston, A.C., McLoyd, V.C. (2002). Economic Well Being and Children's Social Adjustment: The Role of Family Process in an Ethnically Diverse Low Income Sample, In Child Development, 73(3), 935-951.

Nevzorov, V.N., Kirko, V.I., Koptseva, N.P., Matskevich, I.V., Teplyashin, V.N., Kozhukhar', E.N., Salykhov, D.V., Kavkin, R.V. (2017). Rekomendatsii po vnedreniyu 
innovatsionnykh tekhnologiy i oborudovaniia pri pererabotke produktsii traditsionnykh promyslov malykh korennykh narodov Severa [Recommendations on Implementation of Innovative Technologies and Equipment for Processing the Products of Traditional Crafts by Indigenous Peoples of the North]. Krasnoyarsk, Krasnoyarsk State Pedagogical University named after V.P. Astafyev, 136 p.

Plan meropriiatiy po realizatsii v 2016-2025 gg. kontseptsii ustoichivogo razvitiia korennykh malochislennykh narodov Severa, Sibiri i Dal'nego Vostoka Rossiyskoi Federatsii [Activity Plan on Realization of the Conception of Sustainable Development for the Indigenous People of the North, Siberia and Far East in the Russian Federation in 2016-2025] (2016). Available at: http:/gov.garant.ru/SESSION/PILOT/main.htm (accessed 5 June 2018).

Vasil'ev, E.A., Kirko, V.I., Malakhova, E.V., Mezhova, I.A., Pimenova, N.N. (2014). Razrabotka modeli i mekhanizmov distantsionnoi podgotovki inzhenernykh i obrazovatel'nykh kadrov (v tom chisle iz malochislennykh korennykh narodov) dlia osvoeniia severnykh $i$ arkticheskikh territoriy Krasnoyarskogo kraia [Simulating Distance Training for Engineering and Educational Personnel (Including Indigenous Peoples) for the Development of the Northern and Arctic Territories of Krasnoyarskiy Krai]. Krasnoyarsk, Krasnoyarsk State Pedagogical University named after V.P. Astafyev, 125 p.

Webley, P., Nyhus, E.K. (2013). Economic Socialization, Saving and Assets in European Young Adults, In Economics of Education Review, 33, 19-30.

Yevseenko, E.A., Kirko, V.I., Malakhova, E.V., Shadrin, A.I. (2016). Metodika opredeleniia napravlennosti professional'noi podgotovki shkol'nikov starshikh klassov [The Methodology of Finding the Direction of Professional Training for Senior Schoolchildren], In Sovremennoye obrazovanie [Modern Education], 4, 65-74. DOI: 10.7256/24098736.2016.4.21478. 


\title{
Экономическая социализация старших школьников в условиях Крайнего Севера
}

\author{
Е.В. Малахова ${ }^{\mathrm{a}}$ В.И. Кирко ${ }^{\mathrm{a}, \boldsymbol{0}}$, М.Г. Янова ${ }^{\mathrm{a}}$ \\ ${ }^{a}$ Красноярский государственный педагогический \\ университет им. В.П. Астафьева \\ Россия, 660049, Красноярск, ул. Ады Лебедевой, 89 \\ ${ }^{6}$ Сибирский федеральньй университет \\ Россия, 660041, Красноярск, пр. Свободньій, 79
}

В работе представлены результаты сравнительных исследований по определению уровня экономической культуры у молодежи старших классов коренных малочисленных народов Севера.

В ходе проведения исследования были изучены условия среды обучающихся, определены уровни соичиализациии школьников, выявлены различия.

Использованная в работе методика может быть применена в образовательных учреждениях среднего и общего образования для дальнейшего повышения уровня экономической культуры обучаюшихся в целях их мотиваџии быть полезными в том сочичме, который они представляют и в котором они проживают.

Выявлена дифференцииация школьников старших классов в уровне их социиальной адаптации, показывающей владение универсальными знаниями для жизни в современной сочиально-экономической среде.

Ключевые слова: экономическая культура, экономическая социализация, старшие школьники, коренные малочисленные народы, условия Крайнего Севера.

Исследование выполнено в рамках регионального конкурса отделения гуманитарных и общественных наук РФФИ «Российское могущество прирастать будет Сибирью и Ледовитым океаном» 2017 - Красноярский край при поддержке КГАУ «Красноярский краевой фонд поддержки научной и научно-технической деятельности». Проект «Развитие и воспроизводство человеческого капитала - основа для улучшения качества жизни коренных малочисленных народов Севера и Арктики Красноярского края в условиях традиционного природопользования» № 17-16-24004.

Научная специальность: 13.00.00 - педагогические науки. 